\title{
Manifestasi Erupsi Alergi Obat Antiretroviral pada Pasien HIV/AIDS di Klinik Teratai RSUP Dr. Hasan Sadikin Bandung Periode 2005 - 2014
}

\author{
Siska Armeinesya ${ }^{1}$, Rasmia Rowawi ${ }^{2}$, Muhammad Ersyad Hamda ${ }^{3}$ \\ ${ }^{1}$ Fakultas Kedokteran Universitas Padjadjaran \\ ${ }^{2}$ Departemen Ilmu Kesehatan Kulit dan Kelamin, Fakultas Kedokteran Universitas Padjadjaran \\ ${ }^{3}$ Departemen Mikrobiologi dan Parasitologi, Fakultas Kedokteran Universitas Padjadjaran
}

\begin{abstract}
Abstrak
Kasus human immunodeficiency virus/acquired immunodeficiency syndrome (HIV/AIDS) telah menjadi masalah kesehatan dunia. High active antiretroviral therapy (HAART) telah menurunkan angka kematian dan kesakitan pada pasien HIV. Pasien HIV memilki risiko tinggi mengalami erupsi alergi obat dibandingkan masyarakat umum. Penelitian ini bertujuan untuk mengindentifikasi manifestasi erupsi alergi obat ARV pada pasien HIV/AIDS periode 2005-2014 di Klinik Teratai RSUP Dr. Hasan Sadikin Bandung. Penelitian ini menggunakan pendekatan cross-sectional. Data dikumpulkan dari rekam medis pasien HIV/AIDS dengan erupsi alergi obat ARV di Klinik Teratai RSUP Dr. Hasan Sadikin Bandung tahun 2005-2014. Dalam penelitian ini didapatkan sebanyak 111 pasien HIV/AIDS mengalami erupsi alergi obat karena ARV. Erupsi alergi obat ARV banyak terjadi pada wanita (55\%) dan pada rentang usia 20-29 tahun (55\%). Jumlah CD4 pada pasien HIV/AIDS dengan erupsi alergi obat saat pertama kali terdiagnosis HIV terbanyak adalah $<200 \mathrm{sel} / \mathrm{mm} 3(55 \%)$. Manifestasi kulit yang paling umum terjadi adalah ruam makulopapular $(89,7 \%)$. Reaksi erupsi alergi obat umumnya disebabkan oleh nevirapin $(82,5 \%)$. Dari penelitian ini didapatkan bahwa ruam makulopapular merupakan manifestasi erupsi alergi obat ARV yang paling sering muncul. Obat yang paling banyak ditemukan menyebabkan erupsi alergi obat adalah nevirapin.
\end{abstract}

Kata kunci : Erupsi alergi obat, HIV/AIDS, obat ARV

\section{Manifestations of Allergic Drug Eruption to Antiretroviral in HIV/AIDS Patients at Teratai Clinic Dr. Hasan Sadikin General Hospital Bandung In $2005-2014$}

\begin{abstract}
Human immunodeficiency virus/acquired immunodeficiency syndrome (HIV/AIDS) has become a global health problem. High active antiretroviral therapy (HAART) has been shown to reduce mortality and morbidity in patients with HIV. HIV patients have the high risk of drug eruption than the general population. Manifestations of allergic drug eruptions varies between individuals. This study aims to identify the manifestations of allergic drug eruption caused by ARV drugs in HIV/AIDS patients in 2005-2014 at Teratai Clinic Dr. Hasan Sadikin General Hospital Bandung. This study used a cross-sectional approach. Data were collected from medical records of HIV/AIDS patient with allergic drug eruption to ARV at Teratai Clinic Dr. Hasan Sadikin Hospital in 2005-2014. In this study 111 HIV/AIDS patients were diagnosed as having allergic drug eruption to ARV. ARV drug eruptions most common occur in women (55\%) and in the age range 20-29 years (55\%). Baseline CD4 counts of majority of was $<200$ cells $/$ $\mathrm{mm} 3(55 \%)$. The most common skin manifestations is a maculopapular rash (89.7\%). Allergic drug eruptions are the most common caused by nevirapine (82.5\%). This study showed that maculopapular rash is a manifestation of ARV drug eruptions that frequently appears. The major culprit in causing allergic drug eruption in this study is nevirapine.
\end{abstract}

Keywords : Allergic drug eruption, antiretroviral drugs, HIV/AIDS

Korespondensi:

Siska Armeinesya

Fakultas Kedokteran Universitas Padjadjaran

Jl. Raya Bandung-Sumedang KM 21 Jatinangor, Sumedang

Mobile : 085294131011

Email : siska.armeinesya@gmail.com 


\section{Pendahuluan}

Kasus human immunodeficiency virus/acquired immunodeficiency syndrome (HIV/AIDS), sejak pertama kali ditemukan tahun 1981 telah menjadi masalah kesehatan dunia. Pada akhir tahun 2014 tercatat sebanyak 36,9 juta orang di dunia hidup dengan HIV. ${ }^{1}$

Kasus HIV/AIDS di Indonesia pertama kali dilaporkan di Bali pada tahun 1987. Sampai saat ini kasus HIV/AIDS sudah tersebar di 381 kabupaten/kota di seluruh provinsi di Indonesia. Jumlah kumulatif infeksi HIV yang dilaporkan dari April 1987 hingga Juni 2015 sebanyak 177.463 dan jumlah kumulatif AIDS sebanyak 67.028 orang. Berdasarkan laporan triwulan Kementerian Kesehatan Republik Indonesia sampai Juni 2015, provinsi dengan angka kasus HIV/AIDS ke empat tertinggi adalah DKI Jakarta, Jawa Timur, Papua, Jawa Barat dan Bali. ${ }^{2}$

High activity antiretroviral therapy (HAART) yang diperkenalkan pada tahun 1996 merupakan kombinasi tiga atau lebih obat antiretroviral (ARV) yang berperan menekan replikasi virus dan meningkatkan nilai CD4+. CD4+ merupakan jenis sel darah putih yang berperan dalam sistem kekebalan tubuh manusia dan sebagai penentu memulai obat ARV. Penggunaan metode HAART secara drastis telah menurunkan angka kematian dan kesakitan pada penderita AIDS. ${ }^{3}$ Banyak pasien HIV yang menghentikan pengobatan terapi ARV, salah satunya disebabkan oleh timbulnya efek samping obat. Sekitar $80 \%$ pasien yang terinfeksi HIV mengalami efek samping obat yang dihubungkan dengan adanya perubahan sistem imun, perubahan metabolisme obat dan polifarmasi obat. ${ }^{4}$ Hal tersebut membuat banyak pasien HIV yang memutuskan untuk menghentikan pengobatannya. Pasien HIV memilki risiko yang tinggi untuk mengalami erupsi obat dibandingkan masyarakat umum. ${ }^{3,4}$

Manifestasi erupsi obat yang terjadi bervariasi antar individu mulai dari yang ringan sampai berat bahkan beberapa kasus sulit untuk diatasi. ${ }^{4}$ Manifestasi erupsi obat yang muncul dapat berupa urtikaria, makulopapular, vaskulitis, eritroderma, hiperpigmentasi, steven johnson syndrome (SJS), dan toxic epidermal necrolysis (TEN). ${ }^{5}$

Deteksi dan tatalaksana dini pada kasus erupsi obat ARV sangat penting, dikarenakan tidak semua erupsi alergi obat harus menghentikan terapi ARV.5 Oleh karena itu sebagai tenaga kesehatan profesional harus mengetahui peluang kejadian erupsi alergi obat dan manifestasi kulit yang muncul agar dapat menentukan terapi yang tepat untuk pasien. Penelitian ini dimaksudkan untuk mengidentifikasi manifestasi erupsi alergi obat ARV pada pasien HIV/AIDS di Klinik
Teratai Rumah Sakit Umum Pusat (RSUP) Dr. Hasan Sadikin Bandung periode 2005-2014.

\section{Metode}

Penelitian dilakukan dari bulan September November 2016 di Klinik Teratai RSUP Dr. Hasan Sadikin menggunakan studi desain deskriptif cross sectional. Klinik Teratai merupakan klinik rujukan HIV di Jawa Barat. Subjek penelitian adalah seluruh pasien HIV/AIDS yang menjalani terapi ARV di Klinik Teratai RSUP Dr. Hasan Sadikin. Instrumen yang digunakan dalam penelitian ini adalah data sekunder berupa data rekam medis pasien. Kriteria inklusi berupa rekam medis pasien HIV/AIDS yang menjalani terapi ARV dan mengalami erupsi alergi obat ARV di Klinik Teratai RSUP Dr. Hasan Sadikin Bandung periode 2005-2014. Data rekam medis pasien tersebut harus mencantumkan diagnosis erupsi obat disertai dengan obat yang diduga sebagai penyebabnya. Kriteria eksklusi berupa data rekam medis yang tidak lengkap. Variabel pada penelitian ini adalah manifestasi erupsi alergi obat ARV dan obat ARV yang diduga sebagai penyebabnya. Jumlah sampel diambil menggunakan metode total sampling. Jumlah sampel yang didapatkan pada penelitian ini adalah sebesar 179 sampel.

Data rekam medis diperoleh dengan terlebih dahulu membuat surat izin penelitian. Etika penelitian telah disetujui oleh Komite Etik Penelitian Kesehatan Fakultas Kedokteran Universitas Padjadjaran Bandung dengan nomor etik 506/UN6.C1.3.2/KEPK/PN/2016. Analisis dilakukan secara deskriptif dengan menghitung jumlah dan persentase. Penelitian ini dimulai dari mengelompokkan rekam medis pasien HIV/ AIDS yang didiagnosis mengalami erupsi alergi obat. Setelah itu, dilihat manifestasi erupsi obat yang muncul serta obat ARV yang diduga sebagai penyebabnya. Jika sudah didapatkan datanya, maka selanjutnya dapat dilakukan analisis data untuk mendapatkan kesimpulan.

\section{Hasil}

Jumlah sampel yang didapatkan pada penelitian ini adalah sebesar 179 sampel, namun hanya 111 data yang dapat dianalisis karena data yang tidak lengkap. Pasien HIV/AIDS dengan erupsi alergi obat di Klinik Teratai RSUP Dr. Hasan Sadikin lebih banyak terjadi pada wanita dan pada pasien dengan rentang usia 20-29 tahun, disusul kelompok usia 30-39 tahun (tabel 1). Sebagian besar kasus erupsi alergi obat ARV pada pasein 
HIV/AIDS terjadi pada kelompok usia produktif yaitu 20-49 tahun yang mencapai 97\%.

\begin{tabular}{ccc}
\multicolumn{3}{c}{$\begin{array}{l}\text { Tabel } 1 \text { Karakteristik pasien HIV/AIDS } \\
\text { dengan erupsi alergi obat ARV di Klinik } \\
\text { Teratai RSUP Dr. Hasan Sadikin Bandung }\end{array}$} \\
\hline $\begin{array}{ccc}\text { Karakteristik } \\
\text { pasien }\end{array}$ & $\begin{array}{c}\text { Jumlah } \\
\text { (n) }\end{array}$ & $\begin{array}{c}\text { Persentase } \\
(\%)\end{array}$ \\
\hline $\begin{array}{c}\text { Umur (tahun) } \\
20-29\end{array}$ & 61 & 55 \\
$30-39$ & 42 & 38 \\
$40-49$ & 5 & 4 \\
$50-59$ & 3 & 3 \\
Jenis Kelamin & & \\
Wanita & 61 & 55 \\
Laki-laki & 50 & 45 \\
\hline
\end{tabular}

Tabel 2 Distribusi jumlah CD4 pasien HIV/ AIDS dengan erupsi alergi obat ARV di Klinik Teratai RSUP Dr. Hasan Sadikin Bandung

\begin{tabular}{ccc}
\hline $\begin{array}{c}\text { Jumlah CD4 } \\
(\mathbf{s e l} / \mathbf{m m 3})\end{array}$ & $\begin{array}{c}\text { Jumlah } \\
(\mathbf{n})\end{array}$ & $\begin{array}{c}\text { Persentase } \\
(\mathbf{\%})\end{array}$ \\
\hline$<200$ & 61 & 55 \\
$200-499$ & 44 & 40 \\
$\geq 500$ & 6 & 5 \\
Total & 111 & 100 \\
\hline
\end{tabular}

Distribusi jumlah CD4 pada pasien HIV/AIDS yang mengalami erupsi obat ARV di Klinik Teratai RSUP Dr. Hasan Sadikin Bandung periode 2005-2014 saat pertama kali terdiagnosis HIV/AIDS terbanyak adalah pada CD4 $<200 \mathrm{sel} /$ mm3 (tabel 2).

Beberapa pasien memiliki lebih dari satu penyebab erupsi obat dan manifestasinya, sehingga terdapat 126 diagnosis yang dibuat dari
111 sampel dalam penelitian ini. Manifestasi erupsi obat ARV terbanyak disebabkan oleh Nevirapin yaitu sebanyak 104 kasus $(82,5 \%)$ dari 126 diagnosis erupsi obat ARV dan manifestasi yang paling sering muncul adalah ruam makulopapular sebanyak 113 kasus $(89,7 \%)$ dari 126 diagnosis erupsi obat ARV (tabel 3).

\section{Pembahasan}

Pada hasil penelitian ini didapatkan bahwa pasien HIV/AIDS yang mengalami erupsi obat ARV di Klinik Teratai RSUP Dr. Hasan Sadikin sebagian besar adalah wanita dengan persentase $55 \%$. Beberapa penelitian sebelumnya terkait hal ini menyatakan hasil yang berbeda-beda. Hasil penelitian yang dilakukan oleh NH Talib dkk di Malaysia menyatakan bahwa jumlah kejadian erupsi obat antara wanita dan laki-laki tidak signifikan berbeda. ${ }^{6}$ Namun terdapat pula penelitian yang mendukung hasil penelitian ini, seperti penelitian yang dilakukan oleh Seema dkk di India yang menyatakan bahwa persentase efek samping obat pada kulit lebih besar terjadi pada wanita. ${ }^{7}$ Hasil yang sama juga diungkapkan pada penelitian yang dilakukan oleh Leelavathy dkk. ${ }^{8}$ Persentase kejadian erupsi alergi obat pada wanita dan laki-laki tergantung pada populasi yang diteliti. Beberapa penelitian sebelumnya menunjukkan bahwa ada perbedaan seks yang potensial pada kejadian erupsi alergi obat ARV. Perbedaan farmakokinetik obat tertentu antara wanita dan laki laki belum diketahui dengan pasti, namun mungkin bisa disebabkan oleh banyak faktor seperti komposisi lemak tubuh, efek hormonal pada metabolisme obat dan aktivitas enzim yang mempengaruhi biotransformasi obat. ${ }^{9}$

Pada penelitian ini, usia pasien HIV/AIDS dengan erupsi alergi obat ARV adalah 20-57 tahun. Sebanyak $55 \%$ pasien berada dalam

Tabel 3 Manifestasi Erupsi alergi obat ARV pada pasien HIV/AIDS di Klinik Teratai RSUP Dr. Hasan Sadikin Bandung

\begin{tabular}{|c|c|c|c|c|c|}
\hline \multicolumn{6}{|c|}{ Manifestasi Kulit } \\
\hline $\begin{array}{c}\text { Obat ARV } \\
\text { yang diduga }\end{array}$ & $\begin{array}{c}\text { Urtikaria } \\
(n=1)\end{array}$ & $\begin{array}{c}\text { Ruam } \\
\text { makulopapular } \\
(\mathrm{n}=113)\end{array}$ & $\begin{array}{l}\text { Eritroderma } \\
\quad(n=1)\end{array}$ & $\begin{array}{c}\text { SJS } \\
(\mathrm{n}=11)\end{array}$ & $\begin{array}{c}\text { Total erupsi } \\
\text { obat } \\
(n=126)\end{array}$ \\
\hline \multicolumn{6}{|l|}{ NRTI } \\
\hline Zidovudin (ZDV) & 0 & $1(0,9)$ & 0 & 0 & $1(0,8)$ \\
\hline Tenofovir (TDF) & 0 & $2(1,8)$ & 0 & $1(9,1)$ & $3(2,4)$ \\
\hline \multicolumn{6}{|l|}{ NNRTI } \\
\hline Nevirapin (NVP) & 0 & $96(84,9)$ & 0 & $8(72,7)$ & $104(82,5)$ \\
\hline Efavirenz (EFV) & $1(100)$ & $14(12,4)$ & $1(100)$ & $2(18,2)$ & $18(14,3)$ \\
\hline
\end{tabular}


kelompok usia 20-29 tahun, diikuti oleh kelompok usia 30-39 sebanyak 38\%. Peranan usia pada kasus erupsi alergi obat pada beberapa penelitian berbeda-beda. Hasil penelitian ini sesuai dengan penelitian Mayur dkk yang menunjukkan bahwa persentase efek samping obat pada kulit lebih banyak terjadi pada kelompok usia 21-40 tahun. ${ }^{10}$ Penelitian yang dilakukan oleh Margaret dkk, di Ghana juga menyatakan bahwa efek samping obat umumnya terjadi pada usia reproduktif. ${ }^{11}$ Meningkatnya kejadian erupsi alergi obat ARV pada usia produktif mungkin disebabkan oleh sistem imun dalam tubuh sudah lebih matang. ${ }^{12}$

Hasil penelitian ini menunjukkan sebanyak 54 kasus (55\%) erupsi alelergi obat ARV pada pasien HIV/AIDS mempunyai jumlah CD4 $<200 \mathrm{sel} /$ $\mathrm{mm}^{3}$. Radhakrishnan dkk juga menyatakan bahwa pasien dengan jumlah CD4 $<200 \mathrm{sel} / \mathrm{mm}^{3}$ yang paling banyak mengalami efek samping obat. ${ }^{3}$ Hal ini bisa dikaitkan dengan adanya disregulasi sistem imun yang terjadi pada pasien HIV/AIDS yang menyebabkan penurunan sel CD4 sehingga mudah mengalami rekasi hipersensitivitas terhadap obat. ${ }^{13}$ Selain itu, mungkin disebabkan karena memang indikasi pemberian obat ARV pada pasien HIV/AIDS adalah CD4 $<350 \mathrm{sel} /$ $\mathrm{mm}^{3}$ sehingga populasi yang ditemukan pada penelitian ini banyak pada CD4 $<200 \mathrm{sel} / \mathrm{mm}^{3}$. $^{10}$

Pada penelitian ini didapatkan bahwa erupsi obat ARV pada pasien HIV/AIDS terbanyak disebabkanolehnevirapinyaitu 104 kasus $(82,5 \%)$. Sampai saat ini belum ada pemeriksaan atau tes untuk menentukan obat yang menyebabkan erupsi alergi obat. Dalam menentukan penyebabnya, world health organization (WHO) menetapkan kriteria kausalitas untuk erupsi alergi obat yang terdiri dari certain, probable, possible, unlikely, unclassified dan unclassifiable. ${ }^{14}$ Pada penelitian ini diagnosis kasus erupsi alergi obat hanya berdasarkan anamnesis, temuan klinis dan epidemiologi. Hasil penelitian Mayur dkk menyatakan bahwa nevirapin merupakan obat ARV yang paling umum menyebabkan erupsi alergi obat. ${ }^{10}$ Penelitian yang dilakukan Mohamed dkk dan Leelavathy dkk juga menyatakan hal yang sama. ${ }^{15,16}$

Selain nevirapin, ada beberapa obat ARV yang juga dikaitkan dengan kejadian erupsi alergi obat seperti zidovudin (2,9\%), lamivudin $(2,9 \%)$, tenofovir $(5-7 \%)$ dan efavirenz $(14,5 \%),{ }^{5,10}$ Beberapa penelitian sebelumnya juga menyebutkan obat ARV yang dikaitkan dengan erupsi obat pada pasien HIV/AIDS. ${ }^{11}$

Manifestasi erupsi obat ARV yang banyak ditemukan pada penelitian ini berupa ruam makulopapular yaitu 113 kasus $(89,7)$, diikuti oleh SJS sebanyak 11 kasus $(8,7 \%)$. Selain itu juga terdapat manifestasi seperti urtikaria sebanyak 1 kasus $(0,8 \%)$ dan eritroderma sebanyak 1 kasus $(0,8 \%)$. Hasil penelitian Mayur dkk juga menyatakan hal yang sama bahwa ruam makulopapular merupakan manifestasi erupsi obat yang paling sering terjadi. ${ }^{10}$ Hal yang sama juga diungkapkan dalam penelitian yang dilakukan oleh NH Talib dkk, dikatakan bahwa ruam makulopapular merupakan manifestasi erupsi obat yang paling sering muncul, diikuti oleh SJS. ${ }^{6}$

Keterbatasan dari penelitian ini diantaranya diagnosis erupsi alergi obat dibuat berdasarkan temuan klinis dan epidemiologi, belum ada tes spesifik yang dapat menentukan penyebab pasti dari erupsi alergi obat yang terjadi pada pasien. Keterbatasan lain dari penelitian ini adalah ketidaklengkapan data di rekam medis RSUP Dr. Hasan Sadikin, khususnya tentang manifestasi erupsi obat yang muncul pada pasien HIV/AIDS.

Dari penelitian ini didapatkan bahwa nevirapin merupakan obat ARV yang sering menyebabkan reaksi erupsi obat pada pasien HIV/AIDS. Manifestasi ruam makulopapular merupakan manifestasi yang paling umum muncul pada pasien HIV/AIDS yang mengalami erupsi obat ARV. Hasil penelitian ini dapat dijadikan acuan untuk melakukan penelitian lebih lanjut mengenai kandungan obat ARV yang dapat menimbulkan erupsi alergi obat pada pasien HIV/AIDS.

Sebelum pemberian HAART, tenaga kesehatan profesional harus menanyakan riwayat alergi obat pada pasien atau keluarga dan memberitahu informasi kepada pasien tentang risiko terjadinya erupsi alergi obat dan ruam kulit yang dapat timbul akibat obat ARV dan obat lain yang diberikan.

\section{Daftar Pustaka}

1. The Joint United Nations Programme. FastTrack to ending AIDS. New York; 2016.

2. Kementrian Kesehatan RI. Laporan situasi perkembangan HIV/AIDS di Indonesia tahun 2015. Indonesia; 2015.

3. Rajesh R, Vidyasagar S, Nandakumar K. Highly active antiretroviral therapy induced adverse drug reactions in Indian human immunodeficiency virus positive patients. Int J Pharm Sci. 2011;9(1):48-55.

4. Rajesh R, Vidyasagar S, Johnson S, Singh S, Sharma S. Highly active antiretroviral therapy induced cutaneous adverse drug reactions in patients with human immunodeficiency virus infection. Int J Pharm Sci. 2010;2(2):84-97.

5. Yunihastuti E, Widhani A, Karjadi TH. Drug hypersensitivity in human immunodeficiency virus-infected patient: challenging diagnosis 
and management. Asia Pac Allergy. 2014;4(1):54-67.

6. Talib NH, Leelavathi M, Hamzah Z. Common adverse cutaneous drug reaction patterns and the causative drugs in Malaysia. South African Fam Pract. 2015;57(4):227-30.

7. Seema Q, Bisati S, Manzoor S, Sameem F, Khan K. Adverse cutaneous drug reactions - a clinico-demographic study in a tertiary care teaching hospital of the kashmir valley, India. Arch Iran Med. 2015;18(4):228-33.

8. Budamakuntla L, Challa N, Basappa P, Puttappa C. A Retrospective study of spectrum of nevirapine induced cutaneous drug reactions in HIV positive patients. J USChina Med Sci. 2015;12:85-9.

9. Ofotokun I, Chuck SK, Hitti JE. Antiretroviral pharmacokinetic profile: a review of sex differences. Gend Med. 2007;4(2):106-19.

10. Pawar MP, Pore SM, Pradhan SN, Burute SR, Bhoi UY, Ramanand SJ. Nevirapine: most common cause of cutaneous adverse drug reactions in an outpatient department of a tertiary care hospital. J Clin Diagnostic Res. 2015;9(11):17-20.

11. Lartey M, Asante-Quashie A, Essel A, Kenu E, Ganu V, Neequaye a. Adverse drug reactions to antiretroviral therapy during the early art period at a tertiary hospital in Ghana. PanAfrican Med J. 2014;18(25):1-6.
12. Barlianto W. Faktor-faktor yang mempengaruhi derajat keparahan erupsi obat pada anak factors affecting drug eruption severity in children. J Kedokt Brawijaya. 2010;26(1):53-6.

13. OkoyeAA, Picker LJ.CD4+ Tcell depletion in HIV infection: mechanism of immunological failure. Immunol Rev. 2014;254(1):54-64.

14. Yadav S, Pillai KK, Kapur P. Causality assessment of suspected adverse drug reaction with anti-tubercular therapy by WHO probability scale. J Appl Pharm Sci. 2011;01(01):26-9.

15. Cissé M, Tounkara TM, Diané BF, Soumah MM, Keita M, Sako FB, et al. Severe drug eruption in Guinea Conakry. J Cosmet dermatological Sci Appl. 2014;4(5):339-43.

16. Budamakuntla L, Challa N, Basappa P, Puttappa C. A retrospective study of spectrum of nevirapine induced cutaneous drug reactions in HIV positive patients. J USChina Med Sci. 2015;12(1):85-9. 